\title{
An Empirical Analysis of Food Security and Public Distribution System
}

\author{
K. Mohan Reddy \\ Associate Professor and Head, Department of Economics, Kakatiya University, Warangal, Telangana, India \\ E-Mail: mohanreddykalsani@gmail.com
}

\begin{abstract}
The present study deals with an empirical analysis of food security and public distribution system. The present paper deals with the importance of food security and public distribution system and objectives and methodology. Further, it is devoted to examine the food security and public distribution system. This paper is primarily based on the data gathered from primary as well as various secondary sources, especially those related to the availability of the statistical information pertaining to food security and public distribution system. The researcher is of the opinion that there is a need to improve the quality of grains supplied from PDS. By and large, it can be said that the sample respondents offered many suggestions for a better functioning of the system. The suggestions that they offered comprise of an improvement in the quality of goods supplied through FPSs, an increase in the quantity of goods, regular supply from govt., and preventing black marketing by dealers and elimination of bogus cards. Keywords: Food Security, Public Distribution System
\end{abstract}

\section{INTRODUCTION}

The term household food security is referred to as, access by all people at all times to enough food for an active healthy life e'. In a large number of alternative definitions of this term, the emphasis remains, however, just short of access to enough food for all, ensured through a right to secured livelihood during normal time and (a right) to get compensated for the loss (decline or deterioration) in it during emergency [1]. At the macro level, food security is achieved by the State by i) having sufficient access to food for all its citizens- through own production, stocks or trade; and ii) guaranteeing everyone (right to) such access. It represents a condition in which the probability of a country"s citizen"s consumption falling below minimum levels of food consumption - a function of international and domestic variables is very low. The focus of most of the definitions of household food security is its transitory component. It tends to save vulnerable groups from the adverse impact of wide fluctuations in agricultural production by i) making foodgrains accessible nearby, and ii) protecting them from sharp increases in food grain prices.

The design of the Indian public distribution system until recently [2] was to insulate the poor and the under nourished from sharp increases in food grain prices by providing them subsidized food grain. PDS in India has had an urban bias till the mid-1970s (Lipton, 1981); the massive expansion of fair price shops (FPSs) in rural areas during the 1970s. Rajasthan shows the highest rural bias, although only less than 9 per cent of the rural population used PDS for the purchase of food grain even in a year of drought. At the aggregate level, however, household food security during the years of extreme drought, e.g., 1987-88, could only be achieved through the twin instruments of employment programmes and the access to foodgrains through PDS.

Of the two components of food-insecurity, the transitory component and the chronic component, it is the former which assumes greater importance for Rajasthan. The State is nearly self-sufficient in its food grain requirements on an average of a quinquennium. However, due to very harsh climatic conditions, moderate to very high transitory food insecurity is experienced in one part of the State or the other in almost all the years. Also, from the point of view of the management of PDS, it is necessary to identify the nature of food security that it seeks to provide.

There is a consensus among the economists that the food security in the form of public distribution system that has evolved in the economy since the mid-sixties has been able to eliminate famines and also to bring a substantial measure of relief to the consumers during years of acute scarcity. It is true that the food problem in the sense of inadequacy and shortage of foodgrains no longer exists. But the food problem in the normative sense still continues to exist as millions of poor suffer from persistent hunger and malnutrition. Another problem is the rapidly rising prices of foodgrains. It has made more and more difficult for the poor to meet their essential food requirements from the markets over a period of time [3].

\section{REVIEW OF LITERATURE}

It may be pertinent to argue that in any policy for poverty alleviation and hence improving food security, stabilizing food grain prices is likely to be more effective than augmenting foodgrains output. To Dantwala by keeping food grain prices high, policy makers in India have displayed a big farmer and anti-poor bias. Some economists like Binswanger and Quizon (1984), Janvory and Subbarao (1984) also point out that an increase in domestic food production per se will not reduce food insecurity unless accompanied by price reductions. Again, given the growing regional disparities, in income, food grain production and prices, markets operate in such a way that they do not in any way ensure food grain availability mainly in the rural areas largely because of rural-urban income and price differentials (CDS, 1975). All these would imply a larger role for the 
PDS in ensuring food security, particularly in the rural sector by ensuring physical access of food to the rural areas where massive poverty is located among the rural landless, the small farmers and the marginal's who are the net buyers of food in the market.

The basic objective of the PDS in India is to provide essential consumers goods at cheap and subsidized prices to the consumers so as to insulate them from the impact of rising prices and maintain the minimum nutritional status of our population [4]. Apart from the grains, mainly wheat and rice, the PDS is also used for the distribution of edible oils, sugar, coal, kerosene and cloth. PDS in India covers the whole population as no means of direct targeting are yet substantially employed. (Sib Ranjan Misra, 2004)

To ensure food security to weaker sections of the society, Government has been implementing a number of programmes, schemes such as Targeted Public Distribution System (TPDS) focused on Below Poverty Line (BPL) families, Other Welfare Schemes such as Mid- Day Meal Scheme of School Children Integrated Child Development Services Scheme (ICDS) for pre-school. Children and mothers, Annapurna Scheme for indigent citizens who are not eligible for National Old age Pension/benefits under other schemes of Government and Village Grain Banks Scheme (VGB). However, to ensure food security to all citizens of the country based on rights approach; there is need for providing a statutory basis to food security. (Amrnani, et al., 2011)

The concept of food security includes people s access to basic food products, both physically and economically. The problem of access to basic foods is particularly acute for the vulnerable sections of the society and in the deficit and inaccessible regions of the country. Food security implies a situation where everyone has access, at all times, to the food needed for an active and healthy life. Thus, the essential elements of food security are:

1. Adequate availability of food,

2. Efficient distribution through trade or public distribution system; and

3. Availability of purchasing power in the hands of the people.

By the mid-1990s food security was recognized as a significant concern, spanning a spectrum from the individual to the global level. However, access now involved sufficient food indicating continuing concern with protein-energy malnutrition. But the definition was broadened to incorporate food safety and also nutritional balance, reflecting concerns about food composition and minor nutrient requirements for an active and healthy life. The World Food Summit (1996) adopted a still more complex definition: "Food security, at the individual, household, national, regional and global levels is achieved when all people, at all times, have physical and economic access to sufficient, safe and nutritious food to meet their dietary needs and food preferences for an active and healthy life".
The PDS, which has its origin in the Second World War period, has been an important source for enhancing the food security of the poor. The central government has the responsibility for the supply of rice, wheat, sugar, imported edible oils, and kerosene to the State governments and these items are distributed through a network of 4.5 lakh retail outlets known as fair price shops. A number of studies on PDS have brought out the problems of PDS such as inadequate coverage, lack of price advantage, leakages, urban bias and inefficiencies of handling agencies, including Food Corporation of India (George, 1999). Consumer subsidy for 1998-99 was estimated to be Rs. 4.75 for one kilogram of rice and Rs.4.20 for one kilogram of Wheat. In view of the increased subsidy involved in the operation, from June 1997 a revised scheme of distribution known as the Targeted Public Distribution System was introduced. The TPDS envisages a two-tier system of delivery to households below poverty line (BPL) and above poverty line (APL) with BPL families receiving foodgrains at heavily subsidized prices. For instance, under the TPDS, a quantity of $10 \mathrm{~kg}^{\text {ee }} \mathrm{s}$ of food grains per family per month is being issued to the States on the basis of the number of BPL families. Thus implicitly, the poorer States are being taken care more than the earlier system. The number of BPL families has been determined on the basis of provisional estimates for 1993-94 made by Planning Commission, based on the methodology of expert group under Professor Lakdawala. Poverty based targeting under TPDS is a major improvement over the erstwhile PDS. Further, in order to plug the leakages and increase the transparency, a number of steps have been taken. These include:

1. Release of food grains to the States subject to satisfactory completion of identification of families.

2. Involvement of Panchayat/Nagar Palikas in the identification exercise as well as for supervision of the work of the fair price shops.

3. Constitution of vigilane committees at fair price shops, Taluk, District and State level; and

4. A system of monitoring and reporting on the working of TPDS.

Keeping all these facets in view, the present paper is aimed at to analyse an empirical analysis of food security and public distribution system.

\section{METHODOLOGY}

The research effort is based on the following objectives:

1. To evaluate the impact of the scheme on the objective of securing food security to the poorest of the poor; and

2. To suggest corrective measures to improve the performance of the PDS based on the field findings.

The Research Design adopted for the study is to examine an evaluation of public distribution system in general and the functioning of PDS in Warangal District in particular. Tadvai mandal of the Mulugu Division of the Warangal district had been chosen for the study. The study area at glance had been presented in Table I. 
TABLE I STUdy AREA AT A GLANCE

\begin{tabular}{|c|c|c|c|c|}
\hline $\begin{array}{c}\text { Name of the } \\
\text { Division }\end{array}$ & $\begin{array}{c}\text { Name of the } \\
\text { Mandal }\end{array}$ & $\begin{array}{c}\text { Name of the } \\
\text { Village }\end{array}$ & $\begin{array}{c}\text { Distance from the } \\
\text { Mandal }\end{array}$ & $\begin{array}{c}\text { No. of sample Households } \\
\text { in the villages }\end{array}$ \\
\hline \multirow{2}{*}{ Mulugu } & Tadvai & Katapur & 14 & 60 \\
\cline { 3 - 5 } & Lingala & 50 & 60 \\
\hline
\end{tabular}

The villages are Katapur, Lingala in Tadvai mandal. Among these villages, the BPL households are having the highest number in Katapur village and the Lingala village is having the lowest number of BPL households. From one mandal two villages had been chosen. The field investigation had been taken up during 2016-17 and the data relate to the 2015-16 reference year. The primary data have been collected through administering the structured interview schedules to the designed sample households to obtain the required information.

\section{RESULTS AND DISCUSSION}

The present section had been devoted to an empirical analysis of food security and public distribution system. In this section, as per requirement of the study, the field study was conducted in two villages of one mandal in Warangal district by covering 60 samples from each village and altogether the data had been collected from the 120 sample households in the study area.

Caste-wise distribution of the sample households as per the type of ration card had been presented in Table II. During the field work, the researcher had observed that the ration cards issued are of three types - White, Anthodaya and Annapurna. Of the total sample households, it can be said that the percentage of white card households are higher with 89.2 per cent. Further, while looking at the caste-wise composition, 35 households from ST, 27 households from SC and only 5 households from OC with 29.20 per cent, 22.5 per cent and 4.2 per cent respectively are having the white ration cards and the remaining households are having the Anthodaya and Annapurna cards and only one household is possessing the Annapurna card.

TABle Ii Caste-Wise Distribution Of The SAmple Households As PER The TyPe Of RATION CARD

\begin{tabular}{|c|c|c|c|c|c|c|}
\hline \multirow{2}{*}{ Mandal } & \multirow{2}{*}{$\begin{array}{l}\text { Type of } \\
\text { ration card }\end{array}$} & \multicolumn{4}{|c|}{ Caste } & \multirow{2}{*}{ Total } \\
\hline & & SC & ST & BC & OC & \\
\hline \multirow{8}{*}{ Tadvai } & \multirow{2}{*}{ White } & 27 & 35 & 40 & 5 & 107 \\
\hline & & $(22.5)$ & $(29.2)$ & (33.3) & $(4.2)$ & (89.2) \\
\hline & \multirow{2}{*}{ Anthodaya } & 3 & 6 & 3 & - & 12 \\
\hline & & $(2.5)$ & (5.0) & $(2.5)$ & & $(10.0)$ \\
\hline & \multirow{2}{*}{ Annapurna } & - & 1 & - & - & 1 \\
\hline & & & $(0.8)$ & & & $(0.8)$ \\
\hline & \multirow{2}{*}{ Total } & 30 & 42 & 43 & 5 & 120 \\
\hline & & $(25.0)$ & $(35.0)$ & (35.8) & $(4.2)$ & $(100.0)$ \\
\hline
\end{tabular}

Source: Field study and hereafter refers to the same

Note: Figures in parentheses indicate percentages and hereafter refers to the same
By and large, while looking at the Table, it can be observed that an overwhelming majority of the sample households are having the white ration card facility. During the field work, the researcher had also observed that most of the OC households in the study area in general and the sample households in particular are not eligible to get the white ration cards due to the conditionalities beset with the issuance of the white ration cards. Therefore, it is quite but natural that $\mathrm{OC}$ households may not have the white ration cards as in the case of BC, SC and ST households.

Table Iit Caste-Wise Distribution Of The SAmple Households As Per Utilization Of The Ration Quota

\begin{tabular}{|c|c|c|c|c|c|c|}
\hline \multirow{2}{*}{ Mandal } & \multirow{2}{*}{$\begin{array}{c}\text { Utilization } \\
\text { the ration } \\
\text { quota }\end{array}$} & \multicolumn{4}{|c|}{ Caste } & \multirow[t]{2}{*}{ Total } \\
\hline & & SC & ST & BC & OC & \\
\hline \multirow{6}{*}{ Tadvai } & \multirow{2}{*}{$\begin{array}{l}\text { Every } \\
\text { Month }\end{array}$} & 26 & 36 & 38 & 5 & 105 \\
\hline & & (21.7) & (30.0) & (31.7) & (4.2) & (87.5) \\
\hline & \multirow{2}{*}{ Occasionally } & 4 & 6 & 5 & - & 15 \\
\hline & & (3.3) & $(5.0)$ & $(4.2)$ & & (12.5) \\
\hline & \multirow{2}{*}{ Total } & 30 & 42 & 43 & 5 & 120 \\
\hline & & (25.0) & (35.0) & (35.8) & (4.2) & $(100.0)$ \\
\hline
\end{tabular}

Table III shows about the caste-wise distribution of the sample households as per utilizing the ration quota. While looking at the Table, it can be said that an overwhelming majority of the sample households are utilizing their ration quota every month. 87.5 per cent of the households are drawing their ration quota every month and 12.5 per cent are occasionally purchasing food grains from FPSs, whereas 31.7 per cent of households from BC, 30 per cent of households from ST, 21.7 per cent of households from SC and only 4.2 per cent of households from OC are drawing their quota every month and the remaining per cent of households are occasionally purchasing PDS items.

Therefore, from the above analysis, it can be inferred that almost all the sample households are consuming the ration quota every month. But while looking at the caste-wise composition, $\mathrm{BC}$ households are utilizing their ration quota more regularly. During the field work, it had also been observed that the lower strata of households depend more heavily on PDS items.

Table IV deals with the caste-wise distribution of the sample respondents as per the opening days in a month. It is important factor in the proper functioning of PDS. From the Table, it can be said that a majority of the sample households i.e. 69.2 per cent of households stated that the opening days in a month is one week and above. While looking at the caste-wise particulars, 26.7 per cent of BC 
households, 21.7 per cent of ST households, 15.8 per cent of SC households and 5 per cent of OC households opined that the opening days in a month is one week and above and the remaining 30.8 per cent of households were of the view that the opening days in a month is less than one week. Therefore, from the above analysis, the researcher had also observed that the opening days are reported to be about one week.

Table Iv Caste-Wise Distribution Of The Sample Households As Per The Opinion About The Opening Days In A Month

\begin{tabular}{|c|c|c|c|c|c|c|}
\hline \multirow{2}{*}{ Mandal } & \multirow{2}{*}{$\begin{array}{c}\text { Opinion } \\
\text { about } \\
\text { Opening } \\
\text { days }\end{array}$} & \multicolumn{4}{|c|}{ Caste } & \multirow{2}{*}{ Total } \\
\hline & & SC & ST & BC & OC & \\
\hline \multirow{6}{*}{ Tadvai } & \multirow{2}{*}{$\begin{array}{l}<\text { one } \\
\text { week }\end{array}$} & 11 & 14 & 8 & 4 & 37 \\
\hline & & $(9.2)$ & (11.7) & (6.7) & (3.3) & $(30.8)$ \\
\hline & \multirow{2}{*}{$\begin{array}{l}\text { Above one } \\
\text { week }\end{array}$} & 19 & 26 & 32 & 6 & 83 \\
\hline & & (15.8) & (21.7) & (26.7) & $(5.0)$ & $(69.2)$ \\
\hline & \multirow{2}{*}{ Total } & 30 & 40 & 40 & 10 & 120 \\
\hline & & $(25.0)$ & (33.3) & (33.3) & (8.3) & (100.0) \\
\hline
\end{tabular}

Table V Caste-Wise Distribution Of The Sample Households As Per The QuANTITY Of Rice PuRChASEd From FPSS

\begin{tabular}{|c|c|c|c|c|c|c|}
\hline \multirow{2}{*}{$\begin{array}{l}\text { Mandal } \\
\text { (1) }\end{array}$} & \multirow{2}{*}{$\begin{array}{c}\text { Quantity } \\
\text { of rice } \\
\text { (in kgs.) } \\
(2) \\
\end{array}$} & \multicolumn{4}{|c|}{ Caste } & \multirow{2}{*}{$\begin{array}{c}\text { Total } \\
\text { (7) }\end{array}$} \\
\hline & & $\begin{array}{l}\text { SC } \\
\text { (3) }\end{array}$ & $\begin{array}{l}\text { ST } \\
\text { (4) }\end{array}$ & $\begin{array}{l}\text { BC } \\
\text { (5) }\end{array}$ & $\begin{array}{l}\text { OC } \\
(6)\end{array}$ & \\
\hline \multirow{16}{*}{ Tadvai } & \multirow{2}{*}{4} & 2 & 4 & 2 & - & 8 \\
\hline & & $(1.7)$ & (3.3) & (1.7) & & $(6.7)$ \\
\hline & \multirow{2}{*}{8} & 5 & 9 & 7 & - & 21 \\
\hline & & $(4.2)$ & (7.5) & (5.8) & & $(17.5)$ \\
\hline & \multirow{2}{*}{10} & - & 1 & - & - & 1 \\
\hline & & & $(0.8)$ & & & $(0.8)$ \\
\hline & \multirow{2}{*}{12} & 5 & 8 & 13 & 1 & 27 \\
\hline & & $(4.2)$ & (6.7) & (10.8) & $(0.8)$ & $(22.5)$ \\
\hline & \multirow{2}{*}{16} & 10 & 9 & 11 & 2 & 32 \\
\hline & & (8.3) & (7.5) & $(9.2)$ & (1.7) & (26.7) \\
\hline & \multirow{2}{*}{20} & 5 & 5 & 7 & 2 & 19 \\
\hline & & $(4.2)$ & $(4.2)$ & $(5.8)$ & (1.7) & (15.8) \\
\hline & \multirow{2}{*}{35} & 3 & 6 & 3 & - & 12 \\
\hline & & $(2.5)$ & $(5.0)$ & $(2.5)$ & & $(10.0)$ \\
\hline & \multirow{2}{*}{ Total } & 30 & 42 & 43 & 5 & 120 \\
\hline & & $(25.0)$ & $(35.0)$ & $(35.8)$ & $(4.2)$ & $(100.0)$ \\
\hline
\end{tabular}

Table V deals with the caste-wise distribution of the sample households as per the quantity of rice purchased from FPSs in the study area. A majority of the sample households i.e. 26.7 per cent stated that they are purchasing a quantity of 16 $\mathrm{kgs}$ from FPSs and 9.2 per cent of households from BC, 8.3 per cent of households from SC, 7.5 per cent of households from ST and only 1.7 per cent of households from OC are purchasing $16 \mathrm{kgs}$ per month from FPSs and the remaining households are purchasing $12 \mathrm{kgs}, 8 \mathrm{kgs}, 20 \mathrm{kgs}, 35 \mathrm{kgs}$ and $4 \mathrm{kgs}$ from the FPS and their respective per centages are being $22.5,17.5,15.8,10$, and 6.7 . Thus, from the above analysis, it can be said that a majority of the sample households are not obtaining the sufficient quantity of rice for their families from FPSs and it paves the way for the households to depend on other than FPSs which means general kirana shops to get the remaining quantity of rice. In this regard, during the field work, it had also been observed that the quantum of rice that had been distributed to the families through FPSs as a part and parcel of PDS is inadequate to eke out their families ${ }^{\text {ee }}$ consumption per month and therefore they rely on the private traders. In this regard, the sample households were of the view that the quantity of supply of rice through FPSs should be an adequate quantity.

Table Vi Caste-Wise Distribution Of The SAmple Households As PER The REAsons To Purchase From Fpss

\begin{tabular}{|c|c|c|c|c|c|c|}
\hline \multirow{2}{*}{ Mandal } & \multirow{2}{*}{ Reasons } & \multicolumn{4}{|c|}{ Caste } & \multirow{2}{*}{ Total } \\
\hline & & SC & ST & BC & OC & \\
\hline \multirow{8}{*}{ Tadvai } & \multirow{2}{*}{ Lower Price } & 22 & 34 & 32 & 3 & 91 \\
\hline & & (18.3) & $(28.3)$ & $(26.7)$ & (2.5) & (75.8) \\
\hline & \multirow{2}{*}{$\begin{array}{l}\text { Better Quality } \\
\text { of Commodities }\end{array}$} & 5 & 6 & 7 & - & 18 \\
\hline & & $(4.2)$ & $(5.0)$ & (5.8) & & (15.0) \\
\hline & \multirow{2}{*}{$\begin{array}{l}\text { Availability of } \\
\text { Goods }\end{array}$} & 3 & 2 & 4 & 2 & 11 \\
\hline & & $(2.5)$ & (1.7) & (3.3) & (1.7) & $(9.2)$ \\
\hline & \multirow{2}{*}{ Total } & 30 & 42 & 43 & 5 & 120 \\
\hline & & $(25.0)$ & $(35.0)$ & (35.8) & $(4.2)$ & $(100.0)$ \\
\hline
\end{tabular}

Table VI deals with the caste-wise distribution of the sample households as per the reasons to purchase from FPSs. From the Table, it can be said that the main reasons to purchase from FPSs are split into three -lower price, better quality of commodities and availability of goods. An overwhelming majority of the sample households i.e. 75.8 per cent stated that lower price is one the causes to have the purchases from FPSs and 15 per cent of households stated quality of commodities and 9.2 per cent of households stated the availability of goods are the causes to purchase the items from FPSs.

The caste-wise analysis shows that a majority of the sample households belong to the ST i.e. 28.3 per cent, 26.7 per cent of households from BC, 18.3 per cent of households from $\mathrm{SC}$ and 2.5 per cent of households from OC preferred to purchase from FPSs due to lower price and the remaining households stated better quality of commodities and availability of goods are the reasons to have the items from FPSs. By and large, from the above analysis, it can be surmised that a majority of the sample households expressed that the lower price is one of the reasons to have the purchases from FPSs. Among the SC, ST, BC and OC sample households, a majority of the $\mathrm{BC}$ households are willing to have the commodities from FPSs due to lower price. Therefore, it can be said that among the reasons, lower price is one of the most important causative factors to have the purchases from the FPSs. 
Table ViI CASTE-Wise Distribution Of The SAmple Households As PER THe REASONS For NON-AVAILABILITY OF FOOD GRAINS

\begin{tabular}{|c|c|c|c|c|c|c|}
\hline \multirow{2}{*}{ Mandal } & \multirow{2}{*}{ Reasons } & \multicolumn{4}{|c|}{ Caste } & \multirow{2}{*}{ Total } \\
\hline & & SC & ST & BC & OC & \\
\hline \multirow{10}{*}{ Tadvai } & \multirow{2}{*}{$\begin{array}{l}\text { Not } \\
\text { Applicable }\end{array}$} & 5 & 10 & 7 & 1 & 23 \\
\hline & & $(4.2)$ & (8.3) & $(5.8)$ & $(0.8)$ & (19.2) \\
\hline & \multirow{2}{*}{$\begin{array}{l}\text { Irregular } \\
\text { Supply } \\
\text { From Govt }\end{array}$} & 7 & 15 & 13 & 2 & 37 \\
\hline & & (5.8) & (12.5) & (10.8) & (1.7) & $(30.8)$ \\
\hline & \multirow{2}{*}{$\begin{array}{l}\text { Black } \\
\text { Marketing } \\
\text { By Dealers }\end{array}$} & 17 & 11 & 22 & 1 & 51 \\
\hline & & (14.2) & $(9.2)$ & (18.3) & $(0.8)$ & $(42.5)$ \\
\hline & \multirow{2}{*}{$\begin{array}{l}\text { Lack of } \\
\text { Govt. } \\
\text { Inspection }\end{array}$} & 1 & 6 & 1 & 1 & 9 \\
\hline & & $(0.8)$ & $(5.0)$ & $(0.8)$ & $(0.8)$ & $(7.5)$ \\
\hline & \multirow{2}{*}{ Total } & 30 & 42 & 43 & 5 & 120 \\
\hline & & (25.0) & $(35.0)$ & (35.8) & $(4.2)$ & $(100.0)$ \\
\hline
\end{tabular}

Table VII is a corollary to the Table VI. Out of 120 sample households, 42.5 per cent of households expressed that the reason for non-availability of ration is because of black marketing by dealers, 30.8 per cent of households stated that irregular supply from government and only 7.5 per cent of households expressed that lack of govt. inspection are the reasons for the non-availability of ration. The caste-wise analysis reveals the fact that a relative majority of the sample households belonging to the $\mathrm{BC}$ with 18.3 per cent, 14.2 per cent of SC households, 9.2 per cent of ST households stated that the reason for non-availability of ration is owing to the black marketing by dealers and the remaining households were of the view that non-availability of ration is due to irregular supply from the govt. and lack of govt. inspection. Thus, from the above analysis, it can be observed that there are many reasons for the nonavailability of ration and among them black marketing by dealers, irregular supply from the govt. and lack of govt. inspection are the important reasons. Therefore, in this regard, one can say that if these were eliminated, the problem of non-availability will be ruled out.

Table ViII Caste-Wise Distribution Of The SAmple Households By THE DisTANCE

\begin{tabular}{|c|c|c|c|c|c|c|}
\hline \multirow{2}{*}{ Mandal } & \multirow{2}{*}{ Distance } & \multicolumn{4}{|c|}{ Caste } & \multirow{2}{*}{ Total } \\
\hline & & SC & ST & BC & OC & \\
\hline \multirow{6}{*}{ Tadvai } & \multirow{2}{*}{$<0.5 \mathrm{~km}$} & 23 & 34 & 29 & 3 & 89 \\
\hline & & (19.2) & (28.3) & $(24.2)$ & (2.5) & $(74.2)$ \\
\hline & \multirow{2}{*}{$1.0 \mathrm{~km}$} & 7 & 8 & 14 & 2 & 31 \\
\hline & & $(5.8)$ & (6.7) & (11.7) & (1.7) & $(25.8)$ \\
\hline & \multirow{2}{*}{ Total } & 30 & 42 & 43 & 5 & 120 \\
\hline & & $(25.0)$ & $(35.0)$ & $(35.8)$ & (4.2) & $(100.0)$ \\
\hline
\end{tabular}

Table VIII deals with the caste-wise distribution of the sample respondents by the distance. It is important factor in the proper functioning of PDS. While looking at the Table, it can be said that a majority of the sample households i.e. 74.2 per cent stated that the distance from their residence to
FPSs is below $0.5 \mathrm{~km}$. Out of total sample households, 25.8 per cent of households stated that the distance is $0.5-1 \mathrm{~km}$ from their residence. While looking at the caste-wise particulars, 28.3 per cent of ST households, 24.2 per cent of BC households, 19.2 per cent of SC households and only 2.5 per cent of OC households expressed that the distance is $0.5 \mathrm{~km}$ from their residence. Therefore, from the above analysis the researcher had also observed that the average distance is reported to be about below $0.5 \mathrm{~km}$ from their residence.

TABle IX CASTE-Wise Distribution Of THE SAMPLE HouseHOLdS Opinion About The Opening Days Of The Pds Outlet

\begin{tabular}{|l|l|c|c|c|c|c|}
\hline \multirow{3}{*}{ Mandal } & \multirow{2}{*}{ Opinion } & \multicolumn{4}{|c|}{ Caste } & \multirow{2}{*}{ Total } \\
\cline { 3 - 7 } & & SC & ST & BC & OC & \\
\hline \multirow{4}{*}{ Tadvai } & \multirow{3}{*}{ Sufficient } & 15 & 9 & 20 & 3 & 47 \\
\cline { 3 - 7 } & \multirow{3}{*}{ Not sufficient } & $(12.5)$ & $(7.5)$ & $(16.7)$ & $(2.5)$ & $(39.2)$ \\
\cline { 3 - 7 } & & $(12.5)$ & 33 & 23 & 2 & 73 \\
\cline { 3 - 7 } & \multirow{3}{*}{ Total } & 30 & 42 & 43 & 5 & 120 \\
\cline { 3 - 7 } & & $(25.0)$ & $(35.0)$ & $(35.8)$ & $(4.2)$ & $(100.0)$ \\
\hline
\end{tabular}

Table IX deals with the caste-wise distribution of the sample households"e opinion about the adequacy of the opening days of the PDS outlet. From the Table, it can be said that a majority of the sample households stated that the opening days of FPSs are not sufficient. Of the total sample households, a majority of the sample households i.e. 60.8 per cent stated that the opening days of FPSs are not sufficient and the remaining 39.2 per cent of households stated that the opening days of FPSs are sufficient. 27.5 per cent of ST households, 19.2 per cent of BC households, 12.5 per cent of SC households and 1.7 per cent of OC households elicited that the opening days of FPSs are not sufficient. By and large, from the preceding analysis, irrespective of the caste-wise composition, it can be said that a majority of the sample households expressed that the opening days of FPSs are not sufficient in the study area.

Table X Caste-Wise Sample Households ${ }^{\prime e}$ Opinion About The FUNCTIONING OF THE FPSS

\begin{tabular}{|c|c|c|c|c|c|c|}
\hline \multirow{4}{*}{ Mandal } & \multirow{3}{*}{ Opinion } & \multicolumn{4}{|c|}{ Caste } & \multirow{2}{*}{ Total } \\
\cline { 3 - 7 } & & SC & ST & BC & OC & \\
\hline \multirow{4}{*}{ Tadvai } & \multirow{3}{*}{ Satisfied } & 12 & 8 & 12 & - & 32 \\
\cline { 3 - 7 } & \multirow{2}{*}{ Dissatisfied } & 18 & 34 & 31 & 5 & 88 \\
\cline { 3 - 7 } & & $(10.0)$ & $(6.7)$ & $(10.0)$ & & $(26.7)$ \\
\cline { 3 - 7 } & \multirow{3}{*}{ Total } & 30 & 42 & 43 & 5 & 120 \\
\cline { 3 - 7 } & & $(25.0)$ & $(35.0)$ & $(35.8)$ & $(4.2)$ & $(100.0)$ \\
\hline
\end{tabular}

Table X deals with the caste-wise sample householdse opinion about the functioning of the FPSs. From the Table, it can be said that an overwhelming majority of the sample households in the study area as a whole opined that the 
functioning of FPSs is not satisfactory. Of the total sample households, 73.3 per cent expressed that they are dissatisfied with the functioning of FPSs. Among the households those who had stated dissatisfied with the functioning of FPSs, a majority of the sample households are from ST i.e. 28.3 per cent followed by BC, SC and OC households with 25.8 per cent, 15 per cent and 4.2 per cent respectively. In this regard, during the field work, it had also been observed that owing to the limitations beset with the functioning of FPSs, almost all the sample households lamented that the functioning of FPSs is not satisfactory.

Table Xi Caste-Wise Distribution Of The Sample Households As Per The Opinion About The Rating Of The Overall Functioning OF PdS TODAY With That OF 5 Years Ago

\begin{tabular}{|l|l|c|c|c|c|c|}
\hline \multirow{4}{*}{ Mandal } & \multirow{2}{*}{ Opinion } & \multicolumn{4}{|c|}{ Caste } & \multirow{2}{*}{ Total } \\
\cline { 3 - 7 } & & SC & ST & BC & OC & \\
\hline \multirow{4}{*}{ Tadvai } & \multirow{3}{*}{ Same } & 21 & 16 & 30 & 3 & 70 \\
\cline { 3 - 7 } & \multirow{3}{*}{ Worse } & 9 & 26 & 13 & 2 & 50 \\
\cline { 3 - 7 } & & $(7.5)$ & $(21.7)$ & $(10.8)$ & $(1.7)$ & $(41.7)$ \\
\cline { 3 - 7 } & \multirow{3}{*}{ Total } & 30 & 42 & 43 & 5 & 120 \\
\cline { 3 - 7 } & & $(25.0)$ & $(35.0)$ & $(35.8)$ & $(4.2)$ & $(100.0)$ \\
\hline
\end{tabular}

Table XI deals with the caste-wise distribution of the sample households as per the opinion about the rating of the overall functioning of PDS today with that of 5 years ago. From the Table, it can be said that a majority of the sample households in the study area as a whole expressed that the rate of overall functioning of PDS is the same as in the case of earlier period. 25 per cent of households from BC, 17.5 per cent of households from SC, 13.3 per cent of households from ST and only 2.5 per cent of households from OC stated that the rate of overall functioning of PDS is the same and the remaining 41.7 per cent of households stated that the rate of overall functioning of PDS is worse. Thus, from the above analysis, it can be inferred that most of the households opined that the overall functioning of PDS has not made any commendable progress for the promotion of the welfare of the subjects when compared with its functioning of 5 years ago.

Table XII deals with the caste-wise distribution of the sample households as per the opinion about the quantum of quantity of grains in the present compared with the past. While looking at the Table, it can be said that an overwhelming majority of the sample households stated that the quantum of quantity of grains supplied is worse. 69.2 per cent of the sample households opined that the quantum of quantity of grains is worse. Further, while looking at the caste-wise particulars, 25 per cent of ST households, 21.7 per cent of BC households, 20 per cent of SC households and 2.5 per cent of $\mathrm{OC}$ households stated that the quantum of quantity of grains is worse and the remaining 30.8 per cent of households stated that the quantum of quantity of grains is the same.
Table XiI Caste-Wise Distribution Of The SAmple Households As Per The Opinion About The Quantum Of The Quantity OF GRAINS FROM PDS

\begin{tabular}{|c|c|c|c|c|c|c|}
\hline \multirow{2}{*}{ Mandal } & \multirow{2}{*}{$\begin{array}{c}\text { Quantum of } \\
\text { Grains }\end{array}$} & \multicolumn{4}{|c|}{ Caste } & \multirow{2}{*}{ Total } \\
\hline & & SC & ST & BC & OC & \\
\hline \multirow{6}{*}{ Tadvai } & \multirow{2}{*}{ Same } & 6 & 12 & 17 & 2 & 37 \\
\hline & & $(5.0)$ & $(10.0)$ & (14.2) & (1.7) & $(30.8)$ \\
\hline & \multirow{2}{*}{ Worse } & 24 & 30 & 26 & 3 & 83 \\
\hline & & $(20.0)$ & $(25.0)$ & (21.7) & (2.5) & $(69.2)$ \\
\hline & \multirow{2}{*}{ Total } & 30 & 42 & 43 & 5 & 120 \\
\hline & & $(25.0)$ & $(35.0)$ & (35.8) & (4.2) & $(100.0)$ \\
\hline
\end{tabular}

From the above analysis, it can be said that an overwhelming majority of the sample households opined that the quantum of quantity of grains is worse. Therefore, there is a need to increase the quantity of grains supplied from PDS.

Table XiII Caste-Wise Distribution Of The Sample Households As Per The Opinion About The Rating Of The Quality OF GRAINS FROM PDS

\begin{tabular}{|c|c|c|c|c|c|c|}
\hline \multirow{2}{*}{ Mandal } & \multirow{2}{*}{$\begin{array}{c}\text { Quality of } \\
\text { Grains }\end{array}$} & \multicolumn{4}{|c|}{ Caste } & \multirow{2}{*}{ Total } \\
\hline & & SC & ST & BC & OC & \\
\hline \multirow{8}{*}{ Tadvai } & \multirow{2}{*}{ Better } & & 2 & 2 & - & 4 \\
\hline & & & (1.7) & (1.7) & & (3.3) \\
\hline & \multirow{2}{*}{ Same } & 10 & 16 & 19 & 2 & 47 \\
\hline & & (8.3) & (13.3) & (15.8) & (1.7) & (39.2) \\
\hline & \multirow{2}{*}{ Worse } & 20 & 24 & 22 & 3 & 69 \\
\hline & & (16.7) & $(20.0)$ & (18.3) & (2.5) & (57.5) \\
\hline & \multirow{2}{*}{ Total } & 30 & 42 & 43 & 5 & 120 \\
\hline & & $(25.0)$ & $(35.0)$ & (35.8) & (4.2) & $(100.0)$ \\
\hline
\end{tabular}

Table XIII deals with the caste-wise distribution of the sample households as per the nature of quality of grains. While looking at the Table, it can be said that a majority of the sample households stated that the nature of quality of grains is worse. 57.5 per cent of the sample households opined that the nature of quality of grains is worse. Further, while looking at the caste-wise particulars, 20 per cent of ST households, 18.3 per cent of BC households, 16.7 per cent of SC households and 2.5 per cent of OC households stated that the rating of quality of grains is worse and the remaining 39.2 per cent of households were of the view that the rating of quality of grains is the same and only 3.3 per cent of households opined that the rating of quality of grains is better.

By and large, from the above analysis, it can be said that an overwhelming majority of the sample households were of the view that the rating of quality of grains from PDS is worse. Therefore, there is a need to improve the quality of grains supplied from PDS. 


\section{CONCLUSION}

By and large, from the analysis, it had also been observed that owing to the limitations beset with the functioning of FPSs, almost all the sample households expressed their dissatisfaction in respect of the functioning of FPSs. Thus, it can be stated that most of the households opined that the overall functioning of PDS has not made any commendable progress for the promotion of the welfare of the subjects as and when compared with its performance now with that of 5 years ago. Further, it can be said that an overwhelming majority of the sample households opined that the quantum of quantity of grains is not adequate. Therefore, there is a need to increase the quantity of grains supplied from PDS. Further, it can be said that an overwhelming majority of the sample households were of the view that the rate of quality of grains from PDS is worse. Therefore, there is a need to improve the quality of grains supplied from PDS. Therefore, it can be said that the sample respondents offered many suggestions for a better functioning of the system. The suggestions that they offered comprise of an improvement in the quality of goods supplied through FPSs, an increase in the quantity of goods, regular supply from govt., and preventing black marketing by dealers and elimination of bogus cards.

\section{NOTES}

1. It is the determined claim to the perceived right to employment by millions of poor men and (especially) women, if necessary by marching, picketing and rioting, which is considered as an important factor explaining public action during the drought of the 1970 s in Maharashtra. The Rs. $2 \mathrm{~kg}$ rice scheme of
Andhra Pradesh successes partially because the poor considered that it is a right bestowed on them by Anna, the elder brother.

2. Between 1991 and 1994, the FPS price of Wheat has nearly doubled.

3. The new index of food grains prices (with base 1981$82=100$ ) which stood at 118 in $1982-83$ rose to $1997-98$ and further to 410 in December, 1998.

4. The PDS has been one of the most important elements in India's safety net system for almost 50 years. This is quite clear from the fact that it handles about 15 per cent of the total availability of Rice and Wheat. The PDS costs about 0.5 per cent of GDP and 6 per cent of the Central Government's revenue.

\section{REFERENCES}

[1] Council for Development Studies. (1975). Poverty, Unemployment and Development, United Nations, New York.

[2] Sib Ranjan Misra. (2004). Public Distribution System in India: Some Critical Issues, in Amalesh Banerjee (Ed.), Food Security and Public Distribution System Today, Kanishka Publishers and Distributors, New Delhi.

[3] Amrnani, P. et al., (2011). Role of Law in Food Security Issues in India, Paper Presented at National Seminar on Food security Issues Role and Challenges of Agri-input sector, Acharya N.G. Ranga Agricultural University, Hyderabad.

[4] George, P.S (1999), Some Reflections on Food Security in India, Indian Journal of Agricultural Economics, 54(4), 465-89.

[5] Madhura Swaminathan. (1996). Structural Adjustment, Food Security and System of Public Distribution of Food, Economic and Political Weekly, 31(26), 1665-1672.

[6] Mooij, E Jos. (1994). Public Distribution System as a Safety Net: Who is Saved? Economic and Political Weekly, 29(3), 119-126.

[7] Suryanarayana, M. H. (1997). PDS Reform and Scope for Commodity Based Targeting, Economic and Political Weekly, $30(13), 687-695$. 